\title{
Proceedings of the
}

\section{CAMBRIDGE PHILOSOPHICAL}

\section{SOCIETY}

(MATHEMATICAL AND PHYSICAL SCIENCES)

VOLUME 74

PART 3

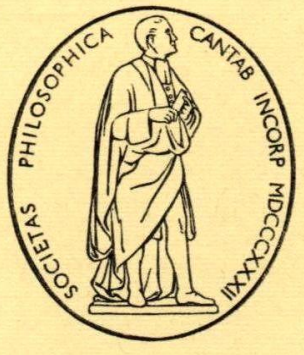

\section{CAMBRIDGE UNIVERSITY PRESS}

BENTLEY HOUSE, 200 EUSTON ROAD, LONDON, NWI 2 DB AMERICAN BRANCH: 32 EAST 57TH STREET, NEW YORK, N.Y.10022

Price £4 Net (U.S.A. and Canada US \$14.00)

1973 subscription price $£ 10$ per volume ( $£ 20$ per annum) net post free November 1973

(US $\$ 32.50$ per volume (US $\$ 65.00$ per annum) in U.S.A. and Canada) 


\title{
Session 1972-1973
}

\author{
President: R. C. EVANS \\ Treasurer: S. G. FLEET \\ Secretaries: (Physical) J. E. FIELD \\ (Biological) M. A. MESSAGE \\ (Mathematical) A. R. D. MATHIAS
}

Vice-Presidents: GEORGE SALT, J.N. AGAR, M. ABERCROMBIE

The publications of the Society consist of the Proceedings and of the Biological Reviews. The publication of Transactions was suspended at the end of Volume XXIII.

Orders may be sent to any bookseller or subscription agent or direct to Cambridge University Press, P.O. Box 92, London NW1 2DB, or in the U.S.A. and Canada, Cambridge University Press, American Branch, 32 East 57th Street, New York, N.Y. 10022.

For the purchase of Transactions and early parts of the Proceedings and Biological Reviews, application should be made to the Secretaries, CamBridge Philosophical Society, BENE'T Streat, CAMBRID Ge, ENGLAND. All parts of the Proceedings (including the cumulative index to Vols. 1 to 50) and of Biological Reviews are available and prices of sets of single parts will be quoted on application.

Fellows and Associates of the Society are particularly requested to inform the Secretaries of any change of postal address and to send their subscriptions to the Treasurer, at the Society's office.

All correspondence regarding library exchanges and Fellows' copies should be addressed to the Librarian at the Society's office.

\section{PROCEEDINGS of the \\ CAMBRIDGE PHILOSOPHICAL SOCIETY edited by}

\section{A. R. D. MATHIAS}

\section{H. T. CROFT \\ J. M. C. SCOTT \\ J. E. ROSEBLADE}

in consultation with

L. E. FRAENKEL
J. A. HUDSON
C. R. F. MAUNDER

\author{
D. J.H. GARLING \\ G. K. EAGLESON
}

1. Proceedings of the Cambridge Philosophical Society is published once every two months. Three issues form a volume and two volumes are published each year. The 1973 subscription price (which includes postage) of a volume is $£ 10$ net (US \$32.50 in the U.S.A. and Canada). Papers in all branches of mathematics (including applications of mathematics in the natural and biological sciences) are within its scope.

2. Contributions for the Proceedings should be sent to the Mathematical Secretary at the Society's office (see above). Papers should be communicated directly by the authors.

3. Papers in languages other than English should be accompanied by a brief summary in English.

4. It is extremely helpful if diagrams are drawn in indian ink on white card, faintly blue or green-lined graph paper, or tracing cloth or paper. Symbols, legends and captions should be given on a transparent overlay. The Society recognizes that many authors do not have the facilities for producing drawings of a sufficiently high standard to be reproduced directly and it is therefore willing to have such diagrams re-drawn, provided they are reasonably clear.

5. References should be listed and numbered at the end of each paper and referred to by number in the text. Titles of journals should be abbreviated as in Mathematical Reviews.

6. Authors are particularly requested to prepare their manuscripts in a form suitable for printing, with adequate margins. The Secretary reserves the right to return scarcely legible manuscripts to the author. A pamphlet on the preparation of manuscripts may be obtained on application to the Librarian. If a large number of corrections are required in the proofs, the Gouncil reserves the right to make a charge towards the cost.

7. Authors may receive on request 100 free offprints (for each set of authors in the case of a joint paper). Alternatively authors may have 50 free offprints in covers. Further copies may be obtained at reasonable cost. An order form is included with the galley proofs of each paper.

8. Second class postage paid at New York, N.Y.

9. (c) Cambridge Philosophical Society, 1973.

For permission to reproduce material from Proceedings of the Cambridge Philosophical Society, please apply to the London or New York office of Cambridge University Press.

ISI Tear Service, 325 Chestnut Street, Philadelphia, Pennsylvania 19106, U.S.A. is authorized to supply single copies of separate articles for private use only. 